\title{
Changes in the relationship between society and nature in the Mezzo-region of Southeastern Pará, Amazon, Brazil
}

\author{
Maurilio de Abreu MONTEIRO'1, Maria Célia Nunes COELHO², Regiane Paracampos da SILVA ${ }^{3}$
}

\begin{abstract}
With this work, the authors wish to show some of the alterations in the pattern of relations between society and nature, which have taken place throughout the $20^{\text {th }}$ century in the Parauapebas and Itacaiúnas river valleys, as well as in parts of the Tocantins River valley, in southeastern Pará. This is accomplished through descriptions based on Coudreau's first-hand accounts (1889), transcribed in "Voyage a Itaboca et a L'Itacayuna", published in 1897, which depicts an area almost totally covered by forest. This is followed by a counter view made possible through the LandSat 5 satellite sensors, with images of those valleys in 2001, showing the consequences of society transformations and pressure on natural resources, and above all the dramatic decrease in the size of the forest, reduced to 52 percent of the 63,000 square kilometers analyzed herein.
\end{abstract}

KEYWORDS: Amazonia; spatial changes; natural resources; Tocantins River Valley, Itacaiúnas River Valley.

\section{Mudanças na relação sociedade/natureza na Mesorregião do Sudeste Paraense, Amazônia, Brasil}

\section{RESUMO}

Neste texto, busca-se demonstrar algumas das alteraçóes ocorridas nos padróes de relaçôes existentes entre sociedade e natureza ocorridas no século XX, nos vales dos rios Parauapebas, Itacaiúnas e em parte do vale rio Tocantins, no sudeste do estado do Pará, o que é feito realizando um resgate das descriçóes decorrentes do olhar de Coudreau (1889) e transcritas em "Voyage a Itaboca et a L'Itacayuna”, publicado em 1897, no qual se descreve uma área quase que integralmente coberta pela floresta. Em seguida, realiza-se uma contraposição, recorrendo a outro olhar, o que é viabilizado pelos sensores do satélite Landsat 5 , que imagiaram a área destes vales em 2001, explicitando conseqüências das transformaçôes da sociedade e da pressão sobre recursos naturais mas, sobretudo, a drástica redução da floresta a $52 \%$ dos 63 mil km² analisados.

PALAVRAS-CHAVE: Amazônia; mudanças espaciais; recursos naturais; vale do Tocantins, vale do Itacaiúnas.

1 Universidade Federal do Pará - UFPA. E-mail: maurilio_naea@ufpa.br

2 Universidade Federal do Rio de Janeiro. E-mail: nunes_coelho@terra.com.br

${ }^{3}$ Núcleo de Altos Estudos Amazônicos. E-mail: rparacampos@hotmail.com 


\section{INTRODUCTION}

This article provides a comparison between the past and present and highlights changes occurring within the regional context regarding relations between society and nature, in order to attain an analytical view of the areas that form the Mezzo-region of Southeastern Pará. Nature and society are understood as dialectically linked entities within the timespace dynamic.

The references used in this analysis, despite being distinct in many aspects, enable a comparison of two representative periods of standards constructed around said relation - or relations, considering the existing diversity, both in nature as well as in societies. Henri Coudreau was a traveler who visited the Tocantins River valley and some of its tributaries in the late $19^{\text {th }}$ century, particularly Itacaiúnas and Parauapebas, the latter being a tributary of the former. Coudreau also climbed the slopes of the Carajás mountain range, a massif that divides the two abovementioned rivers. He described a scenario radically different from that observed at the end of the $20^{\text {th }}$ century, when large-scale projects, represented by the Tucuruí hydro plant, which dammed the waters of the Tocantins in the 1980s and the machinery installed in the Carajás range to mine for iron more or less during the same period, are hallmarks of the profound changes in parts of Southeastern Pará.

This article highlights specific elements that enable a comparison of periods through the relation between society and nature. It assesses forms of land use and occupation, where forest cover appears as a relevant indicator; as well as agents and social groups, their interests and actions, especially institutions and scales of power responsible for dominion over land, rivers, forests, mineral resources, etc and patterns of appropriation and use of natural resources.

\section{METHODOLOGY}

The area of study was analyzed using two instruments: a travelers report, where Henri Coudreau ([1897] 1980) presents his descriptions; and a presentation of Landsat 5 (2001) orbital, satellite image analyses. The paper then conducts a comparative analysis and discussion of the relations between society and nature during the two periods: the late $19^{\text {th }}$ century and the beginning of the $21^{\text {st }}$ century. Despite the long interval separating the two, 104 years, each period is representative of hegemonic patterns of relationship between society and nature in space and in time, with a critical point of inflection in the 1970s and 1980s.

Since we began by following Coudreau's reports on the rivers and river valleys he traveled, we had to delimit the water basins, which we did using the river hierarchy method proposed by Strahler (1952). This method consists in placing channels in a hierarchy based on bifurcation relations, attributing an increasing order to them beginning with tributary-less rivers, which receive the weight of 1 . When two rivers of value 1 meet, a weight (or order) of 2 is attributed to the channel segment isolated by that confluence. Next, two rivers with a value of 2 form a segment of channel of type 3 and so on. Whenever rivers of different hierarchies meet, the higher order of value prevails. The main river is classified by the weight it presents at its mouth, and then the hierarchy of the basin as a whole is established.

Specifically regarding the traveler's report, we must stress that it is a set of direct observations, resulting from empirically addressing space or the landscape. Phenomena are observed (empirical evidence) in succession as the journey progresses, without necessarily any synthesis of the spaces visited, which reveals the inductive method implicit in Coudreau's work ([1897] 1980). Within the more general scientific contest of its time, his report strives to impart something of the expeditions that sought to unveil the world little known to Europeans - the oceans, deserts, savannas, rainforests and mountains of Africa, Asia and America. The available instruments used at that time, such as the compass, complemented the observations.

Orbital images, on the other hand, enable direct contact with the space, while at the same time, the satellite can cover a larger surface area. By basing the analysis on a larger area, a synthesis can be reached more quickly, using deduction. Landsat 5 images used were captured in 2001, at orbit reference points 224/063, 224/064 and 223/064. Orbital images were treated and vectorized using SPRING software developed by the National Space Research Institute (INPE Brazil). The same tool enabled a multi-spectral classification into area units where land cover was the variable used: forest; logging; secondary forest; productive area; water; cloud; cloud shadow; rock outcroping; urban area; sand; floodplain.

The methodology also included a review of literature, a survey of documents and maps and field work, since indirect analysis through geoprocessing tools and other laboratory techniques are insufficient to understand a given space. Furthermore, for purposes of comparison, direct observation, as done earlier by Coudreau ([1897] 1980), was necessary, focusing on the most relevant facts while on-site.

\section{RUBBER AND BRAZIL NUTS IN THE ITACAIÚNAS AND PARAUAPEBAS RIVER VALLEYS}

During the rubber boom period in the late $19^{\text {th }}$ century, Henri Coudreau, together with his wife, Madame Coudreau, sailed down the Itacaiúnas River and some of its tributaries between July $1^{\text {st }}$ and October $11^{\text {th }} 1897$. After his trip, Coudreau wrote a report entitled "Voyage a Itaboca et a L'Itacayuna” (Coudreau [1897] 1890). 
Coudreau's (1980) mission was to conduct a detailed study on the Itaboca Falls, in the region now corresponding to Tucuruí, and to explore the Itacaiúnas River, a tributary on the left margin of the Tocantins River, which flows into this river a short distance from the agricultural village of Itacaiúnas, today the city center of the municipality of Marabá (Figure 1).

He described the forest which then covered the uplands, as he had seen them from the Itacaiúnas River, as very rich in Brazil nuts and in "some samples of the Itacaiúnas 'caucho' (rubber)", the two resources exploited by local collectors, justifying therefore their infrequent incursions into the forest in the late $19^{\text {th }}$ century. He characterized the rubber latex as difficult to coagulate and rated it at a lower price than that produced by the Para rubber tree (Hevea brasiliensis).

Coudreau seemed surprised with the high density of Brazil nut trees, which covered the upland areas as far as the eye could see. He pointed out that in some stretches of the forest covering the hills, the trees formed "plant communities" or even "groves". For Coudreau, "Brazil nut groves are the true resources, moreso than the Itacaiúnas rubber" (Coudreau, 1980). The river, according to Coudreau, was named after the nut groves, since tacá or tucá means nut. Ironically, he called the gatherers and caucheiros the last "civilized" men.

He stressed the small scale of the extractive activities in the following texts:

In front of a small rapid called "Seco do Saranzal", four abandoned barges, at the right bank, once more prove that the local species of rubber has not been able to secure the survival of those who devoted themselves to rubber tapping.

Even at this point, which is almost dry [up stream on the Cachoera Grande falls], we still find the remains of the recent passage of civilized people: leftovers from rubber collectors, who carried their exploitations up to this place (Coudreau, 1980).

The low population number in the village was stressed in statements such as:

One finds almost only people "passing by" among the "inhabitants" of the Itacaiúnas. The few families who actually work along the river banks are so attached to the land that they do not even bother to build - for shelter - the traditional huts, which can be seen in a great number on other river banks. A mere roof made of palm leaves, 2 meters long and as tall as a sitting person: this is the local dwelling of a civilized man! A temporary dwelling, it's true, but whole families live beneath such poor shelters; small human groups, whose members stretch their hammocks not very high from the floor, under a dozen palm trees, which form the wild roof only 1 meter above their heads (Coudreau, 1980).
About the preference for extractive activities rather than agriculture, he wrote:

Among the Itacaiúnas "inhabitants", there is not even one who has - until today - started a roça (small crop). It is true that not even one year has gone by since people started to settle along the banks of this river, but the absence of any trace of culture does not seem to indicate any idea of definite intention to stay. The exploitation of the special rubber found along the Itacaiúnas is still on its primary stage - one cannot deny it - but as one can observe, there seems to be a great deal of doubt about its success (Coudreau, 1980).

The region was covered in primary forest until the end of the $19^{\text {th }}$ century, Coudreau pointed out a significant number of subsistence crops and even cattle, reported by the author as relevant only in the middle valleys of the Tocantins and Araguaia rivers. Therefore, in river sub-basins to the west of the middle Tocantins valley, forest products extraction was the predominant activity. This was the case of almost the entire region of the Itacaiúnas valley, rich in rubber and Brazil nut trees, as well as the area around Itacaiúnas'main tributary: the Parauapebas River.

- It was on the Parauapebas River valley that the voyager decided to go further, near the "Parauapeba" island, according to ancient maps made by the first explorers.Coudreau, however, said the island near the mouth of the Parauapebas River should be called "Confluence Island". The irregular landscape and the existence of Brazil nut trees on the hill sides were noticed by the observer. For Coudreau, "while the Parauapebas seemed to come from a mountainous area, the upper Itacaiúnas appears to come down from an area of high plateaus" (Coudreau, 1980).

A large mountain range rises above the Pedras Chatas falls and Cachoeira Seca falls, , with "a central rocky crest, which reminds one of the Aribaru mountain range in the Xingu River" (Coudreau, 1980).

Proceeding with his trip up to the Parauapebas River, Coudreau finds a rather solid range - the Serra do Parauapebas - with some high peaks measuring 150 meters or more of relative altitude (Coudreau, 1980). The massif referred by Coudreau is a range of mountains, today called Serra dos Carajás. This formation divides the waters forming the basin of the Parauapebas and Itacaiúnas rivers (Figure 1).

Back to the Itacaiúnas River, the author describes large marshes, which almost concealed the Brazil nut groves near "Parauapeba" island. But climbing up the land, the groves appeared in larger numbers.

For Coudreau (1980), the whole area of the Itaboca and Itacaiúnas rivers seemed to be inhabited by only a few indigenous peoples. The voyager came up with the hypothesis 


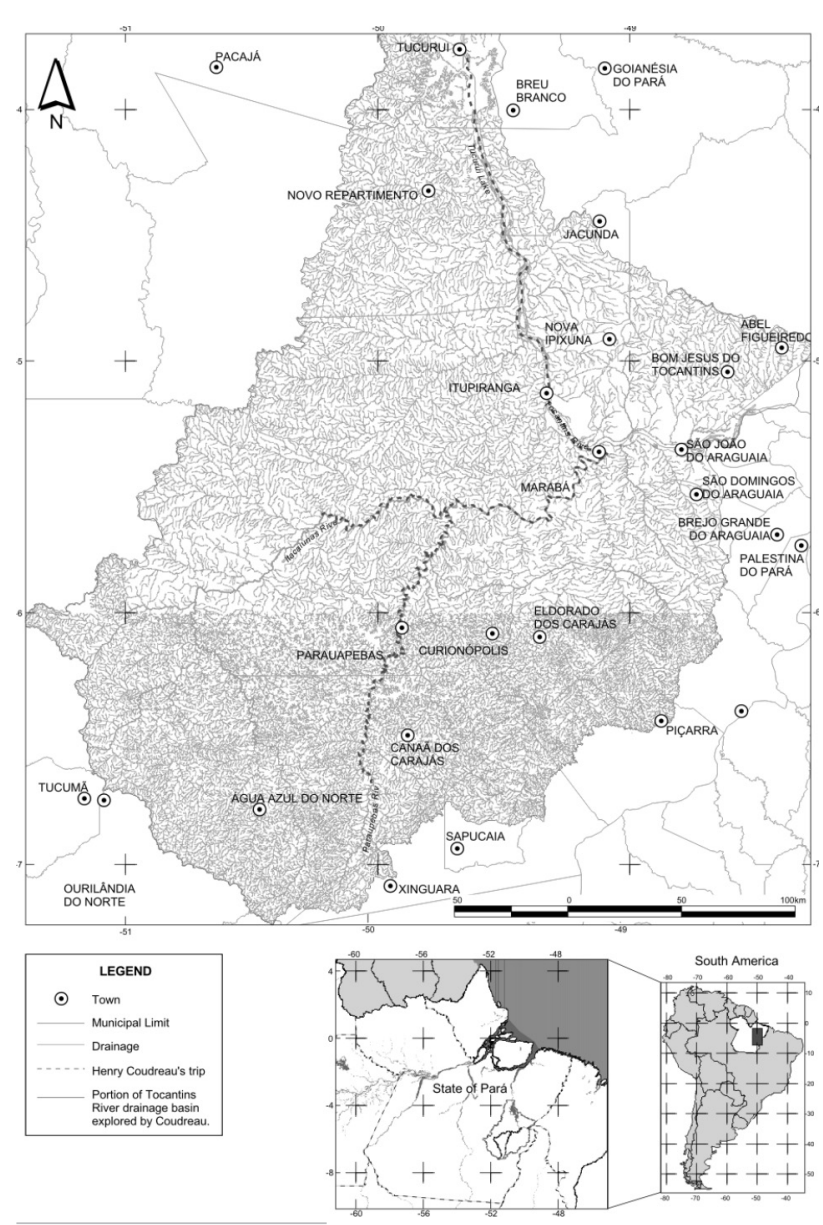

Figure 1 - Portion of Tocantins River drainage basin corresponding to the route explored by Coudreau.

that the "Xickrin indians lived between the Parauapebas and the Araguaia rivers, and the Purucarus on the upper Itacaiúnas and Bacuri" (Coudreau, 1980). According to the writer, the matter would be settled by people who would come afterwards.

\section{NEW PATTERNS FOR RESOURCE USE "INHERITED FROM NATURE"}

Those who travel nowadays throughout southeastern Pará, with an inquiring eye and having read Coudreau (1980), are surprised by the great changes in the relation between nature and society, reflecting the transformation experienced by rural and urban societies, as well as the high degree of urbanization and the dramatic decrease of the original forest. One of the most noticeable changes is the absence of the Brazil nut groves described by Coudreau.

The Brazil nut groveleasing system, created in the 1920 's, followed by the emphyteusis system largely remain a management strategy for preserving the Brazil nut groves to this day. In the 1970's, however, the opening of new roads adopted by the National Integration Program - PIN , first associated with colonization policies and afterwards replaced by fiscal incentives aimed at stimulating ranchers and timber companies, has contributed to the fast decrease of Brazil nut groves. As a consequence, Brazil nut production has decreased dramatically, when considering both the old and new territory of Marabá. The loss of power by the local oligarchy is both cause and consequence of the emerging forms of adding value to natural resources, particularly land. The old emphyteuta (individuals holding "emphyteusis" deeds) began to divide and sell their lands to companies and farmers from southeastern and northeastern Brazil, retaining areas for themselves in order to become ranchers.

Initially, the planning officials did not pay much attention to the fast expansion of cattle ranching, logging, farming, and mining activities, which were soon followed by extended industrial mining activity.

In southeastern Pará, this situation meant that the Brazil nut grove-based oligarchy was losing power (Emmi, 1999), and a new era was beginning, led by other social actors, who began to exploit parts of the Tocantins valley and the right bank of the Itacaiúnas (an area covered by great numbers of Brazil nut groves). Around 1980, the area was demarked and referred to as the Brazil nut Polygon by Executive Group for Lands of the Tocantins-Araguaia - GETAT, in an attempt to preserve them from the accelerated land occupationpressure.

Poor migrants from northeastern Brazil, or small capital holders from the South and Southeast, were all neglected by public policies since 1974. These social groups were involved in a fierce struggle and became a changing power. Organized or otherwise, these groups occupied lands, planted crops and began extensive ranching activities. The changes promoted by small and medium land owners were not restricted to rural settlements - official or not - since benefits from the Special Constitutional Fund for the North - were extended to them from 1990 onwards. In the beginning, this was a financing fund for permanent crops, but at in the late 1990's it was granted to extensive beef ranchers. Without the traditional Brazil nuts and with limited capital, migrants allowed the entrance of loggers, who decimated the Brazil nut trees, along with other species.

By the end of the $20^{\text {th }}$ century, competition among several social actors for gaining access to parts of resources, particularly land, was greatly extended. The landscape resulting from cattle expansion, promoted by large and small land owners, in a production area, became very popular and was frequently referred to as the Brazil nut grove graveyard. The 2001 satellite images show that the forests which harbored Brazil nut groves in this area were wiped out (Figure 2). 
The economic processes of this area are rooted on trading products "inherited from nature", but its economics - in other times based on trading Itacaiúnas rubber, and Brazil nuts (Bertolensis Excelsior) - is now based on other goods "inherited from nature": the water power used to produce electricity; land used for pastures and crops; and iron ore used to fuel blast furnaces of the metallurgy industry.

The Itaboca watersheds, where Coudreau's trip began, no longer exist, submerged by the lake formed by the Tucuruí hydroelectric dam (Figure 2). Large teams of workers were recruited to build this giant hydroelectric dam. In the early 1980 's, the population of the then small town of Tucurui increased to 55,000 people, directly or indirectly involved in the dam building, at a cost of US\$ 5.4 billion - reaching US\$ 7.5 billion when financial costs were added, according to conservative estimates - with a lake that submerged over 2,430 square $\mathrm{km}$ of land (Eletronorte 1984). The construction work used up almost six million cubic meters of concrete and moved approximately 60 million cubic meters of rock and land (Tucuruí, 1981).

Changes in social and ecological relations increased as of the 1970's, when the Transamazon Highway and the Tucuruí Hydroelectric Power Plant were built, in 1984, and the Carajás Project was implemented by Companhia Vale do Rio Doce (CVRD), including the Carajás Railroad, which was concluded in 1985 (Figure 2).

Notwithstanding the fact that economy has remained basically extractive, social structures, which have sustained the predominant economy, have changed greatly in the region. Such changes have dialectically led to the maintenance of an economy based on depletion of natural resources with changes in the type of natural resources valued at the time, as well as changes in social relations. The large electricity company Eletronorte, and the large mining company CVRD played important roles in these changes, supported by Brazilian state development decisions and actions.

\section{IRON ORE IN THE ITACAIÚNAS AND PARAUAPEBAS PLATEAUS}

When Coudreau traveled around the Itacaiúnas valley, he did not associated the mountain range between the Itacaiúnas and Parauapebas rivers with the existence of geochemical or geological anomalies, which later led to the discovery of iron, manganese, and gold. Iron was actually found in 1967. By the end of 1979 and beginning of the 1980's, the Serra |Pelada group was the largest open air gold mine in the world. The gold deposit of Serra Pelada is located in the axis of the mineral province of Carajás (Meireles; Silva, 1988), between Serra Leste and Serra do Sereno. The area is drained by Igarapé do Sereno, a stream that flows into the Parauapebas River. CVRD's mining of iron, manganese (deposits at Azul,

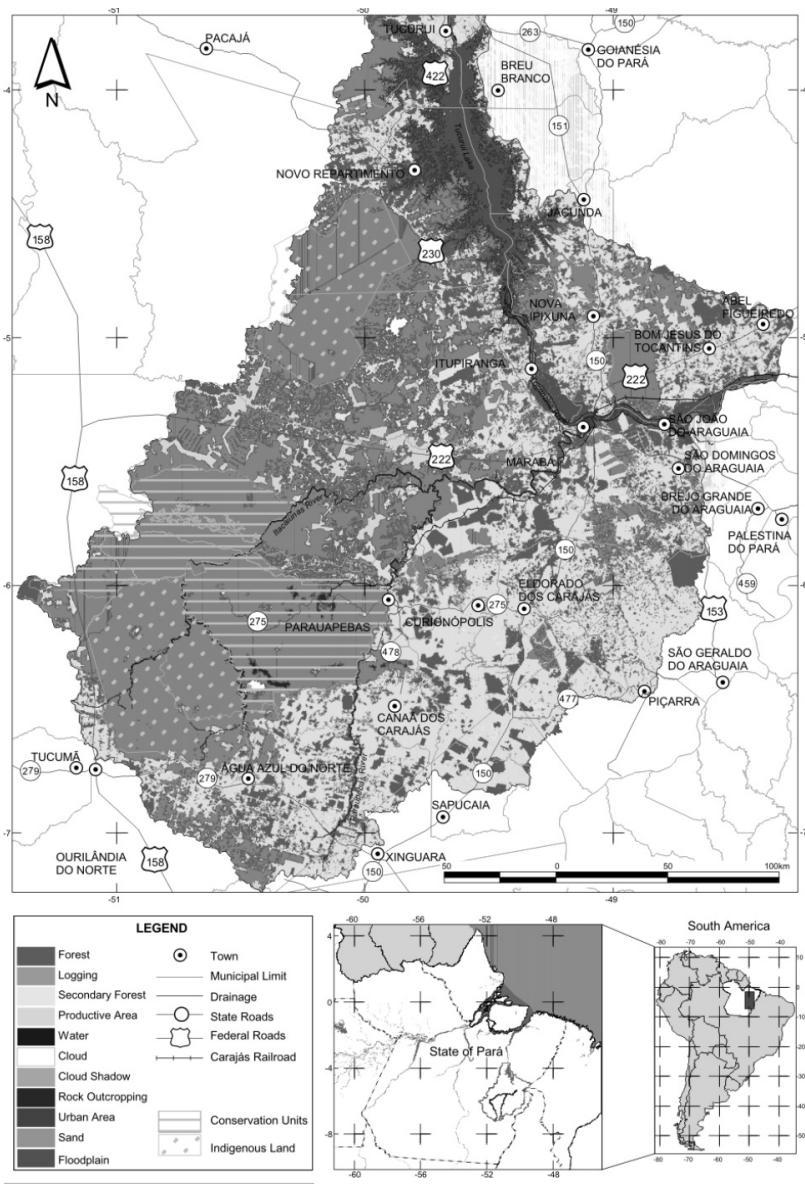

Figure 2 - Multi-spectral classification of area in land cover units.

Buritirama, and Sereno), and more recently gold in Igarapé Bahia (closed in May 2002), are located in Serra Norte.

The discovery of the world's largest mineral province on the plateaus of the Itacaiúnas and Parauapebas rivers was the decisive factor in terms of populating the Parauapebas valley visited by Coudreau in the late $19^{\text {th }}$ century. It was an area located outside the great concentration of Brazil nut groves and free from the presence of extractive farmers. By the end of the 1960's, a report on the iron district of Carajás was presented by CVRD's predecessor, Amazônia Mineração S. A. (AMZA, s.d), characterizing the region as:

[...] totally isolated by the jungle, still today the same Amazon jungle researched by the German naturalist Alexander Von Humboldt around 1800 [here the text omits the fact that Humboldt never set foot on Brazilian territory]. All connections with Serra dos Carajás are made by air. Even in areas where some roads were constructed to support mineral prospect, there is a big dependence on air transport, with the use of helicopters due to its adequate flexibility (AMZA, s.d). 
The abovementioned text identifies Carajás as a complex formed by two mountain ranges, running parallel, one in the north and one in the south, with a distance of approximately 50 kilometers between each (AMZA, s.d.). With flat tops and altitudes ranging from 700 to 800 meters, the mountains called the geologists' attention for the hardpan pro parte, which did not allow the growing of dense vegetation. On this hard soil, existing vegetation was savannah and small woods, very thin and contrasting with the surrounding luxuriant forest. Amazônia Mineraçáo referred to the region as hardly inhabited, with only "a few settlers along the major rivers and a few Indian tribes, sparsely distributed, and with no link to civilization; both groups with poor sanitary and life condition" (AMZA, s.d). Economy was fundamentally based on Brazil nut collection, rubber tapping, and hunting wild animals for their fur.

It is true that Serra dos Carajás was outside the dense Brazil nut groves areas - the best ones were found between the Tocantins and the Itacaiúnas, south of Marabá, near the right bank tributaries of the Itacaiúnas River: Vermelho, Sororó, and Sororozinho, in the municipalities of Marabá and São João do Araguaia, extending to Conceição do Araguaia, as well as in the left bank of the Itacaiúnas, near Itupiranga, Jacundá, and Tucuruí, but not so dense towards the Xingu River area (Velho, 1972) - and therefore away from the area dominated by Brazil nut extractive activities, which continued until the mid-20 $0^{\text {th }}$ century, in southeastern Pará.

The Carajás deposits, when first found, were not near the newly constructed roads, such as the Belém-Brasília and Transamazon, therefore reducing the chances of an invasion of northeast migrants in search of land to ensure their living, or farmers and entrepreneurs who bought lands from Brazil nut emphyteuta in order to convert those lands into pastures, threatening the preservation of the Brazil nut groves.

When iron was discovered in Carajás in the 1960's, one may assume that the land around Serra dos Carajás was not well known and not exploited by indigenous populations. In the early 1980's, federal planners and CVRD regarded the area in the Parauapebas and Itacaiúnas river valleys a large demographic void, with only a few indigenous populations and low demographic density.

\section{DISPUTING NATURAL RESOURCES AND LAND CONTROL}

At the left bank of the Parauapebas River, with fewer Brazil nut groves but location of the main mineral reserves of the region, one may see that most of the forest has been preserved (Figure 2), involving competition for land control among several agents. Here one notices the importance of CVRD's interests, pressuring the government not only for underground control of the region, but also alleging that only by controlling the surface would mining of the underground resources be possible. Several strategies were therefore developed in order to secure, directly or indirectly, control over wide tracts of land by CVRD.

One of the first tools used for securing control over those lands was a Decree-Law issued by the military government in 1971. This Decree-Law established that all lands falling into an area 100 kilometers to each side of all federal roads and railroads, already constructed or planned, would belong to the federal government and would be used for agricultural settlements, coordinated by the National Institute for Colonization and Agrarian Reform- INCRA. According to this law, the national government owned part of the land petitioned by CVRD, still a state-owned company at this point. Since not all areas to be mined by the company belonged to the Union (with a capital "U" - the Federal Republic of Brazil), an important problem remained to be solved by planners: how to make those lands available to CVRD (an issue already raised by AMZA) when only $60 \%$ of the area known as the mineral province of Carajás was located was under federal jurisdiction. The solution was the creation of a map where Union areas could be extended, regardless of claims made by the State of Pará. Thus an expanded area was generated, allegedly for government use in agrarian reform policies, based on the projection of a new imaginary or "planned" road: the BR 158. Based on this new drawing, the entire area corresponding to the mineral province of Carajás now became federal property and, as such, could be granted to the Companhia Vale do Rio Doce (CVRD) by the federal government (Éleres, 1999).

The planned road was never built, but one of its consequences was called "Hourglass", named after the shape of the land that was left outside the areas projected on the map. This land extended to the side of several federal roads, real or imaginary, as established by the 1971 Decree-Law. The location of this land, which bordered lands granted for research conducted by CVRD, was a matter of concern for the company, since such areas would be open to migrations, including areas within the mineral province of Carajás. There was fear that squatters and gold miners would threaten the security of this area, creating obstacles for present and future interests in increasing CVRD's land concessions.

Jurisdiction over lands along all federal roads fell under GETAT. In order to solve existing and future land conflicts, GETAT undertook the task to enforce order in the territory, setting aside an area at the south of the mineral province and at the right bank of the Parauapebas River for the settlement of colonies, thus creating Regional Development CentersCEDERES I, II and III . The settlement in the CEDERES 50-hectare lots, under coordination of the federal government, occurred from 1982 to 1983. This, however, did not prevent 
social conflicts in the 'Hourglass' area, especially in the south, where the Carajás Railway was located. The area was located on the borders of a vast land tract belonging to the Lunardelli family (whose patriarch was a prosperous industrialist from Sáo Paulo, and the "coffee king" in northern Paraná State in the 1960's), as well as lands belonging to Pedro Miranda (a farmer from the State of Goiás) (Bunker, Coelho e Lopes, 2002).

In 1986, without granting all the company's petitions, the Federal Senate granted CVRD an area of 411,948 hectares, corresponding to the Mineral Province of Serra dos Carajás. The land was "considered Union property, extracted from a larger area of 467,000 hectares, previously taken by INCRA and GETAT, through 'discretionary procedures' (government privilege related to land rights) established by Law nr. 6383/76 and registered on behalf of the Union" (Éleres, 1999). This land donation, however, has been contested by the State of Pará, which regards these lands as lands belonging to the state.

An area of 21,600 ha, corresponding to the valley of Igarapé Gelado, in the foothills, near the waste deposit of the Carajás Iron Project, was claimed simultaneously by CVRD and by squatters, on the grounds that those were public lands. Since the early 1980 's, squatters have entered the area, convinced that it did not belong to CVRD. The occupation of the contested area began in 1985, with a few migrants from southeastern Pará and from other states. Around 1989, another hundred families occupied the area. The solution found by CVRD, aided by IBAMA, was to transform the area into an environmental conservation unit for restricted use, thus creating the Igarapé Gelado Environmental Protection Area - APA. Human presence is allowed in the area only if such occupation follows strict rules and natural resources area used in a sustainable manner. According to the Decree which created this area, the APA is subject to supervision and control by IBAMA, which has transferred its responsibility over these lands to CVRD (Figure 2).

The 103,000 hectare area of of dense jungle around the hill was created as a unit classified as the Tapirapé Biological Reserve (Tapirapé Rebio) with even stricter restrictions for use, since the area is set aside for biodiversity protection and as a bio-genetic bank. Public visits are forbidden in the Rebio, thus securing company control over this area.

The Tapirapé-Aquiri National Forest (FLONA TapirapéAquiri) was created in another 190,000 hectare area, located on the banks of the Aquiri and Itacaiúnas rivers in the municipality of Marabá, which includes the CVRD copper reserves (CVRD, Environmental Report, 1999). The creation of this unit allows rational use of renewable natural resources and mineral resources (copper, gold, and manganese). This unit is under IBAMA jurisdiction. CVRD, however, has direct influence in management of this area. The creation of this FLONA allowed the company to mine underground resources and prevent land occupation by former gold miners, squatters and forest product collectors (loggers and others), including other mining companies (Figure 2).

Similarly, and almost ten years after creation of the Tapirapé-Aquiri FLONA and other conservation units in the Carajás area, CVRD obtained authorization for creation of the Carajás FLONA from the federal government through IBAMA. This is a conservation unit which secures the right of mining iron and other ores existing within the already mentioned 411,948 hectares previously granted by the National Congress, provided that the environment is protected and that mining is carried out without disturbing environmental balance.

The creation of a protected zone outside the area granted to CVRD for mining was also aided by the fact that the area bordered, to the west, the Xickrin do Cateté Indigenous Reserve. Moreover, in 1982, due to pressure from the World Bank, CVRD was forced to invest approximately US\$ 12 million in demarcation, education, health and infrastructure programs in the indigenous lands located within those mining areas and area of influence of the Carajás Railroad. In the specific case of the Xickrin do Cateté Indigenous Reserve, CVRD signed a contract with FUNAI to control its borders to the west and to protect the indigenous inhabitants. The administrative demarcation of this area was ratified by a decree in 1991.

With the creation of the Carajás Flona, contested by opponents (Éleres, 1999), CVRD (now a private company) was attempting to protect itself from possible incursions by gold miners, peasants or dispossessed land workers, from protests that could threaten management of such a vast territory, from lawsuits filed by states, which argue that the legal acts that originated the concession area are invalid. The choice of transforming this area into a FLONA, rather than any other type of conservation unit, is due to the fact that this type of unit allows mining, provided that it is conducted in an ecologically sustainable manner.

Therefore, this is a successful strategy to incorporate large areas for use, through which a private company - CVRD is able to exert power over space that is functionally for the company's interests, but not always accessible to other social agents, among them other mining companies.

\section{CHANGES IN THE PARAUAPEBAS AND ITACAIÚNAS VALLEYS AND PART OF THE TOCANTINS RIVER VALLEY}

Modification in the forest cover is one of the most evident forms of change in the Parauapebas and Itacaiúnas river valleys 
and part of the Tocantins River valley during the last century. The analysis conducted through satellite images, modern land use and occupation of $63,836 \mathrm{sq} \mathrm{km}$ of these valleys (Figure 3) indicates how different the landscape of this area is compared to that presented by Coudreau at the end of the $19^{\text {th }}$ century.

In the early $21^{\text {st }}$ century, the primary forest has been dramatically reduced, currently representing only $54 \%$ of the forest cover in an area that was once almost entirely covered by this luxuriant vegetation. The areas with vegetation associated to cattle ranching or farming already occupy $22,894 \mathrm{sq} \mathrm{km}$, corresponding to $35.86 \%$ of the area analyzed (Figure 3). And vegetation cover represented by secondary forest, almost invariably secondary forests in different stages of development, is $3,286 \mathrm{sq} \mathrm{km}$, corresponding to $5.15 \%$ of the areas of the studied valleys (Figure 3).

The consequences of building the Tucuruí Hydroelectric Power Plant, extending throughout more than 2,400 sq km, were not only to the landscape. Since its construction, several ecological changes, such as proliferation of mosquitoes and micro-climatic changes, still under study, have been attributed to it. From a demographic point of view, a great majority of the tens of thousands of workers employed by the enterprise remained in the region, increasing pressure on land and other natural resources.

To the east and west of the Tucuruí Power Plant reservoir, one may notice a high degree of anthropic activities, since the 1980's, mainly along the PA-150 highway (Figure 2). All over this area, the presence of secondary forest is remarkable and it currently advances towards more preserved areas, such as those inhabited by the Amanayés indigenous group, who were previously located nearby the PA-150 highway. FUNAI, together with a working group, is studying the implementation of the "Ribeirinha" Indigenous Land.

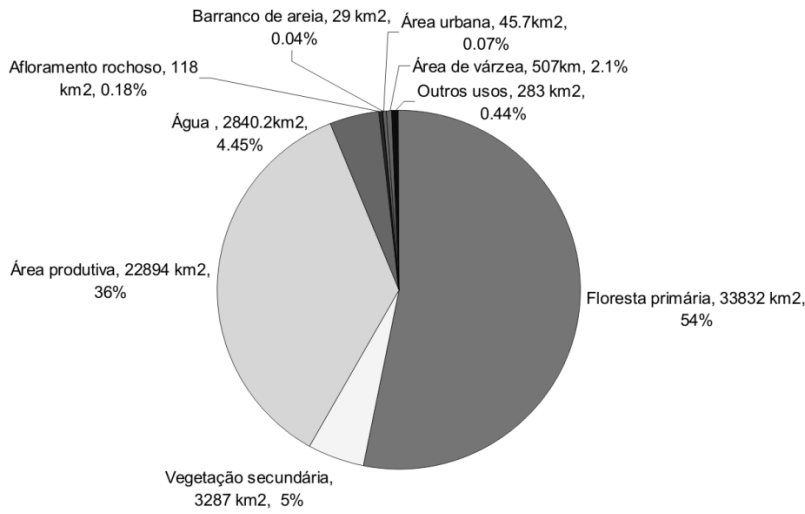

Figure 3 - Graphic representation of the dimension and percentage of land use and occupation classes in the Itacaiúnas and Parauapebas river valleys, and parts of the Tocantins valley, in 2001.

Source: Analysis and classification of LandSat 5 satellite images, in the year 2001, orbits point 224/063, 224/064, 223/063, and 223/064.
Logging almost throughout the entire region was the main factor responsible for transformation of primary forests into secondary vegetation. The occupation process is always characterized by logging of commercial trees, followed by occupation based on cattle ranching activities, and abandonment of the old area moving to new ones, without a relocation program.

Today, the area of the so called Brazil Nut Grove Polygon" is covered by vegetation associated with farming and ranching activities. Non-contiguous forest fragments are present not only in these areas, but also all over the valleys studied herein. These are vulnerable areas, with poor forest cover preservation capacity, due to anthropic pressure on them.

Large spots and fragments of significant primary forests are still found in the Sororó, Mãe Maria, and Parakanã indigenous lands. On the other hand, large areas of almost untouched forest are found in the buttresses of the Serra dos Carajás rocky massif. This is a consequence of CVRD's endeavors to establish a land control mechanism around Serra dos Carajás. Preservation was secured in the areas of the "green belt" represented by the Carajás, Tapirapé-Aquiri FLONAS, by the Tapirapé REBIO, and by the Xickrin do Cateté indigenous lands (Figure 2).

Other impacts have occurred in areas surrounding Serra dos Carajás, mainly caused by removal of forest cover, including settlement areas of GETAT and land corresponding to the Igarapé Gelado Environmental Protection Area (APA) where the railroad is located, as well as an important iron waste deposit disputed by CVRD and squatters.

\section{FINAL CONSIDERATIONS}

The transformations on vegetation and land use in the region are associated to the type of natural resources which were valued at a certain time, due to their characteristics, markets, necessary logistics, and trading value. The shift from a regional economy that once valued Brazil nuts to another that values other natural resources, among them iron ore, has caused structural changes at almost all levels of regional society. Power generation, transport, and communication systems were developed. Migrations, municipal divisions, urban population growth, ranching processes, development and increasing land conflicts, proliferation of rural settlements, demarcation and the new treatment given to indigenous issues, increased deforestation and environmental impoverishment are but a few indications of the changes in the importance of the traded resources.

The social bases that supported the Brazil nut extractive economy have changed. In order to not disappear entirely, however, members of the old rural oligarchy had to renew and develop alliances with new groups of land owners and/or 
with pig iron producers, loggers, and big mining companies. Those who still remain in business cope with the land struggle led by social movements that are increasingly organized. The descendents of the old oligarchy - today independent professionals still owning vast rural areas where they conduct modern cattle raising techniques, using genetic improvements - when elected to the city council still try to seize local power, with or without success, but are far from having the power they used to have in the past.

Mining, cattle ranching, and industry tend to grow, even if not in a very diversified way due to their reproductive logics associated to valuing inherited productive factors instead of socially constituted factors, such as human and social resources (Monteiro, 2005).

The logic behind many activities currently conducted in the valleys analyzed herein is to ensure economic feasibility based on access to a huge amount of environmental resources and services at low cost. One may add to this the fact that activities involving valuing of regional natural resources, seeking short term profit are usually in tandem with hazardous environmental practices, which, in the end, will destroy the very reproductive base of many of these social agents.

\section{LITERATURE CITED}

AMZA, s/d. Amazônia Mineração S.A. Projeto Carajás. Belém, 117 p. 11.

BUNKER, S. 1984. Social Welfare Programs in the Brazilian Amazon, 1970-1975. In: Steven W. Hughes and Kenneth J. Mijeski (eds.). Politics and Public Policy in Latin America. Westview Press, Boulder, Colorado. p. 65-77

BUNKER, S. 1985. Underdeveloping the Amazon. University of Chicago Press. Chicago. 296p

BUNKER, S. 1989. Staples, Links, and Poles in the Construction of Regional Development Theories. Sociological Forum, 4 (December): 589-610.

BUNKER, S. 2001 Notas Sobre A Renda do Solo e a Tributação no Pará. Paper do NAEA, No. 159. Belém, Pará.

BUNKER, S. COELHO, M. C. N. e LOPES, A. 2002 Ferro, Castanha-do-Pará e a Luta pela Terra. O entorno de um Projeto de Mineração na Amazônia Oriental. In: Palheta da Silva, J. M. e outros (Orgs.). Geografia Econômica. Temas Regionais. Editora UNESP São Paulo.p. 16-40.

BUNKER, S.; CICCANTELL, P. 1995. Restructuring Markets, Reorganizing Nature: an Examination of Japanese Strategies for Access to Raw Materials. In: Journal of World Systems Research, Vol. 1. <gopher|lcsf.colorado.edulwsystems $\mid$ journals |l>.

COELHO, M. C. N. 1991. Socioeconomic Impacts of the Carajás Railroad in Maranhão, Brazil. Syracuse University (Tese de Doutoramento). Syracuse. USA

COUDREAU, H. 1898. Voyage a Itaboca et a L'Itacayuna (editado por A. Lahure).

COUDREAU, H. 1980. Viagens a Itaboca e ao Itacaiunas. Editora da Universidade de São Paulo - USP e pela Editora Itatiaia, São Paulo e Belo Horizonte. 117p.

ÉLERES, C. P. de L. 1997 Intervenção Territorial Federal nos Estados-Membros. Relato do Caso do Pará. Centro de Ciências Jurídicas - UFPA (Dissertação de Mestrado apresentada no Curso de Pós-Graduação em Direito). Belém, Pará.

ÉLERES, C. P. de L. 1999 Ação Popular Contra União Federal e Companhia Vale do Rio Doce. Belém, mimeo.

ELETRONORTE 1984. Relatório diagnóstico: reservatório da usina hidrelétrica de Tucuruí., v.1. (Revisão 1). Brasília.

EMMI, M. 1999. A Oligarquia do Tocantins e o Dominio dos Castanhais. UFPA/NAEA, 2a Edição, Belém, Pará. 127p.

MEIRELES, E. de M. e BENEDITO da SILVA, A. R. 1988. Depósito de Ouro de Serra Pelada. In: Principais Depósitos Minerais do Brasil. Vol. III. Brasil, DNPM, , Marabá: 547-557.

MONTEIRO M. A. 2005. Meio século de mineração industrial na Amazônia e suas implicaçóes para o desenvolvimento regional. Estudos Avançados, 19 (53): 187-207.

TUCURUÍ vai gerar o progresso da Amazônia. Planejamento e Desenvolvimento: Seplan, Rio de Janeiro, v. 8, n. 81, p. 32-40, jun./ago 1981.

Recebido em 10/12/2007

Aceito em 06/08/2009 
